\title{
CLINICAL EVALUATION OF THE EFFECTS OF LOW- INTENSITY LASER (GAALAS) ON WOUND HEALING AFTER GINGIVOPLASTY IN HUMANS
}

\author{
AVALIAÇÃO CLINICA DOS EFEITOS DO LASER EM BAIXA INTENSIDADE (GAALAS) NA \\ CICATRIZAÇÃO DE GENGIVOPLASTIA EM HUMANOS
}

Carla Andreotti DAMANTE ${ }^{1}$, Sebastião Luiz Aguiar GREGHI ${ }^{2}$, Adriana Campos Passanezi SANT’ANA², Euloir PASSANEZI ${ }^{3}$

1- MSc in Periodontology by Bauru Dental School - University of São Paulo
2- Professor - Dept. Prosthodontics and Periodontics - Bauru Dental School - University of São Paulo
3- Titular Professor - Dept. Prosthodontics and Periodontics - Bauru Dental School - University of São Paulo

Corresponding address: Sebastião Luiz Aguiar Greghi - Faculdade de Odontologia de Bauru - Departamento de Periodontia - Alameda Octávio Pinheiro Brizolla 9-75 - 17012-901 Bauru - SP - Phone: 55142358278 - e-mail: slagreghi@fob.usp.br

Received: August 25, 2003 - Returned for modification: October 21, 2003 - Accepted: November 20, 2003

\begin{abstract}
L

ow-intensity laser therapy aims at pain suppression, edema reduction and acceleration of wound healing. The main goal of this study was to clinically evaluate the effects of Aluminum Gallium Arsenate laser - 670nm in wound healing after gingivoplasty in 11 patients. Surgery was performed in anterior superior and/or inferior regions. The right side of the patient (test group) received a laser energy density of $4 \mathrm{~J} / \mathrm{cm}^{2}$, in a 48 -hour interval, during one week, totalizing four sessions. The irradiation was punctual in a contact mode in three points. The left side did not receive irradiation (control group). Clinical evaluation was performed by five specialists in periodontology through photography of the treated areas at post-surgical periods of 7, 15, 21,30,60 days. The observers pointed the best healed side. The Sign test was used for statistical analysis with a confidence level of $5 \%(\mathrm{P}<0.05)$. The examiners found a better pattern of healing sometimes in the test and sometimes in the control group until 21 days after surgery. After this period there was no apparent difference between them. There was no statistical difference between the sides $(\mathrm{p}>0.05)$. These results have shown that low-intensity laser therapy did not accelerate oral mucosa healing after gingivoplasty.
\end{abstract}

UNITERMS: Laser; Gingivoplasty; Wound healing.

\begin{abstract}
RESUMO
A

terapia com laser em baixa intensidade visa a biomodulação dos tecidos para se obter supressão da dor, redução do edema, e aceleração da cicatrização. O objetivo deste estudo foi avaliar, clinicamente, os efeitos do laser diodo de arseneto de gálio e alumínio (GaAlAs) - 670nm- na cicatrização de gengivoplastias em 11 pacientes. As cirurgias foram realizadas nas regiões anteriores superior e/ou inferior. O lado direito (teste) foi irradiado, na forma pontual, com $4 \mathrm{~J} / \mathrm{cm}^{2}$ por ponto, em três locais diferentes. A aplicação do laser foi feita a cada 48h, durante uma semana, totalizando quatro sessões. O lado esquerdo (controle) não foi irradiado. A avaliação clínica foi feita por cinco periodontistas, através de fotografias dos períodos pósoperatórios de 7,15,21, 30 e 60 dias. Os examinadores apontaram o lado mais bem cicatrizado ou se ambos estavam iguais. Para análise estatística dos dados clínicos, foi utilizado o teste dos sinais com um nível de significância de 5\% (p<0,05). Os resultados mostraram que havia preferência ora pelo lado teste, ora pelo lado controle até o período de 21 dias e nos períodos subseqüentes ambos os lados foram considerados iguais. A diferença entre os lados estudados não foi estatisticamente significante, sugerindo que o laser não acelerou a cicatrização da mucosa oral.

UNITERMOS: Gengivoplastia; Lasers; Cicatrização de feridas.
\end{abstract}

\section{INTRODUCTION}

Laser is a form of light, as its name indicates - Light Amplification by Stimulated Emission of Radiation. Taking into account that light has been used as a therapeutic agent for centuries, lasers soon became a therapeutic tool within the health sciences.

High intensity lasers use heat for cutting and vaporizing 
tissues and are known as surgical lasers. In a different way, the low-intensity lasers have the capacity of altering cell behavior without an increase in temperature. These lasers have specific wavelengths that act in a molecular level. The biomodulation of cellular behavior is nowadays known by low-intensity laser therapy (LILT). The most important effects of this therapy are pain suppression and acceleration of wound healing.

Mester ${ }^{10}$ was the first researcher to study the effects of low-intensity laser on acceleration of wound healing. His studies showed positive effects of LILT in various biological systems. Experiments in humans resulted in acceleration of healing in non-healing wounds and ulcers after irradiation with low-intensity laser.

There are many papers reporting the use of LILT for acceleration of wound healing, and the majority of them were performed in animals or in vitro ${ }^{3,7,8,9,10,13}$. Some studies in humans can be found, but most are related to extraction of third molars ${ }^{4,5,6,11}$. Therefore, there is a need of more LILT studies in periodontology. Rydén, et al. ${ }^{12}$ studied the effects of this therapy on reduction of gingival inflammation in patients with gingivitis, and did not find statistically significant differences between irradiated and non-irradiated sites according to the plaque index and gingival bleeding. Amorim ${ }^{1}$ obtained acceleration of gingival healing after gingivoplasty in sites irradiated with a low-intensity diode laser.

Due to the lack of human studies on the utilization of LILT for acceleration of wound healing in Periodontology, the aim of this study was to clinically evaluate the effects of low-intensity laser therapy on oral mucosa healing after gingivoplasty.

\section{MATERIALAND METHODS}

Eleven patients presenting inflammatory gingival hyperplasia at superior and/or inferior sextants were selected for this study. Each sextant was considered separately resulting in nineteen areas to be treated by surgery. All patients received oral hygiene instructions, scaling and coronal planning and were put in a rigorous plaque control. After gingivoplasty, the right side (test) received irradiation of Gallium Aluminum Arsenate (GaAlAs) laser (KC 6120 VR
- Kondortech, São Carlos - SP, Brazil), with 670nm wavelength. Just before the study, the manufacturer calibrated the power and wavelength. The application was contact mode in keratinized mucosa corresponding to teeth 11,12,13 or 41, 42, 43. Punctual mode was used in three points of approximately $4 \mathrm{~mm}$ of diameter each, corresponding to the intraoral point diameter. Energy density was calculated and compensation was made for the $20 \%$ reduction in energy caused by the intraoral point. The total energy density applied was $4 \mathrm{~J} / \mathrm{cm}^{2}$ per point. Laser therapy was repeated in a 48-hour interval during one week, totalizing four sessions. The left side, which served as control, did not receive any irradiation.

Photographs of the post-surgical periods of 7, 15, 21, 30 and 60 days were taken for clinical evaluation. Each patient accounted for three images: one closed photograph from test side, one for control side and a third involving both areas. Five blind examiners, experts in Periodontology, who received the information that laser was randomly applied at the right or left sides performed the clinical evaluation. The observers marked in a form the side seemingly presenting a more advanced healing process or if both sides were similar. Gingival color, texture and contour were parameters established for their evaluation. The Sign test was used for statistical analysis at a significance level of $5 \%$. $(\mathrm{P}<0.05)$. The Ethics Committee of University of Sao Paulo approved this study.

\section{RESULTS}

According to Table 1, most examiners have chosen the control side as presenting the fastest healing at 7 and 21 days and the test side at 15 days after surgery. Both sides were considered similar in the following periods. The Sign test showed no statistically significant difference for this evaluation. ( $p>0.05)$.

\section{DISCUSSION}

The literature has been showing controversy in the results of researches with low-level laser. The studies of Mester ${ }^{10}$ and Kana, et al. ${ }^{7}$ have found acceleration on wound

TABLE 1- Number of patients with the best pattern of healing according to examiners' opinion

\begin{tabular}{llllll}
\hline & Test & Control & Equal & z & p \\
\hline 7 days $(n=19)$ & 7 & 8 & 4 & 0 & 1 ns \\
14 days $(n=17)$ & 8 & 4 & 5 & 0.86 & $0.38 \mathrm{~ns}$ \\
21 days $(n=15)$ & 4 & 7 & 4 & 0.6 & $0.54 \mathrm{~ns}$ \\
30 days $(n=19)$ & 1 & 5 & 13 & 1.22 & $0.22 \mathrm{~ns}$ \\
60 days $(n=19)$ & 1 & 2 & 16 & 0 & 1 ns \\
\hline
\end{tabular}

ns - not statisticaly significant 
healing in rats after LILT. From the other side, Braverman, et al. ${ }^{3}$ did not find significant differences in wound healing in rabbits. In vitro studies bring positive results of LILT in proliferation of human fibroblasts ${ }^{8,9}$ and in reduction of prostaglandin E2 production ${ }^{13}$.

It is difficult to interpret laboratory studies on the effect of LILT because of the great variety of animal models and parameters used. Besides, results cannot be expected to be the same in humans. When discussing about in vitro studies, one must have in mind that mechanisms involved in wound healing are complex. There is a link between fibroblast activities, extracellular matrix and growth factors produced by inflammatory cells.

In this study, the clinical analysis showed a tendency of choice of one side or sometimes the other until the postsurgical period of 21 days. Both sides were considered equal in the following periods thereafter. This fact suggests that laser influences the first week of the healing process, although the differences between sides were not statistically significant. Our results differ from that found by Amorim ${ }^{1}$, whose test group was chosen as best healed within the period of 7 to 35 days after surgery.

The majority of human studies do not show positive effects of laser related to acceleration of wound healing ${ }^{4,5,6,11,12}$. Most of these, as well as the present study, used split mouth design for their research, because this model eliminates variables that can occur from patient to patient. This model is often criticized by some authors, who affirm that laser can have a systemic effect ${ }^{14,15}$. They suggest that LILT promotes release of growth factors and other substances in the blood stream, which can reach distant sites of the body. This theory loses validity when observing studies that used split mouth design and obtained better results on lased sites ${ }^{1,10}$. Furthermore, the irradiated areas receive all laser energy density and probably mediators and growth factors released at that sites present local action and are not capable of causing systemic effects.

Another theory discussed in literature is that laser has a pronounced effect on tissues affected by pathological condition ${ }^{15}$. Tuner and Hode ${ }^{15}$ suggest that laser directly affects the immune system, hence healthy organisms do not respond so well as those with immune depression. Some studies confirm this theory showing that LILT accelerated wound healing ${ }^{16}$ and increased production of growth factors ${ }^{2}$ in diabetic mice. On the other hand, Amorim ${ }^{1}$ obtained better results on the lased side even in healthy patients.

In the present study, the patients were young, healthy and showed an excellent healing process after gingivoplasty. All these findings can justify the fact that an evident effect of LILT on the oral mucosa was not obtained. Moreover, lasers in the red spectrum of light have a superficial action, and the energy density of $4 \mathrm{~J} / \mathrm{cm}^{2}$ can be low for reaching any result.

There is a lack of parameters on the literature for lowlevel laser application, which makes any comparison between studies difficult. Additionally, there are many variables such as type of laser, application mode - punctual or scanning, contact or non-contact - dose, wavelength and frequency of irradiation, that also impair comparison between different studies.

Scientific documentation about LILT is still uncompleted. There is the need to establish effective protocols of laser application, allowing this therapy to be used in dental clinics and bring more comfort for the patients.

\section{CONCLUSION}

Within the parameters used in the present study, the low-intensity laser therapy did not accelerate gingival healing.

\section{REFERENCES}

1- Amorim JCF. Reparação gengival após a técnica de gengivectomia e aplicação de laser em baixa intensidade. Avaliação clínica e biométrica em humanos São Paulo; 2001. [Dissertação de Mestrado Profissionalizante - Faculdade de de Odontologia da USP]

2- Anders JJ, Byrnes KR, Barna L, Chenault VM, Longo L, Miracco C. FGF expression increases with low power laser irradiation during healing of cutaneous wounds in normal and diabetic psammomys obesus [abstract]. Lasers Surg Med 2002; (14 suppl):12.

3- Braverman B, McCarthy RJ, Ivankovich AD, Forde DE, Overfield M, Bapna MS. Effect of helium-neon and infrared laser irradiation on wound healing in rabbits. Lasers Surg Med 1989;9(1):50-8.

4- Carrillo JS, Calatayud J, Manso FJ, Barberia E, Martinez JM, Donado M. A randomized double blind clinical trial on the effectiveness of helium-neon laser in the prevention of pain, swelling and trismus after removal of impacted third molars. Int dent $\mathrm{J}$ 1990; 40(1):31-6.

5- Clokie C, Bentley KC, Head TW. The effects of the heliumneon laser on post surgical discomfort: A pilot study. J Canad dent Ass 1991; 57(7):584-6.

6- Fernando S, Hill CM, Walker R. A randomized double blind comparative study of low level laser therapy following surgical extraction of lower third molar teeth. Brit J oral Maxillofac Surg 1993;31(3):170-2.

7- Kana JS, Hutschenreiter G, Haina D, Waidelich W. Effect of low power density laser radiation on healing of open skin wounds in rats. Arch Surg 1981; 116(3):293-6.

8- Kresiler M, Christoffers AB, Al-Haj H, Willershausen B, d'Hoedt B. Low-level 809nm diode laser induced in vitro stimulation of the proliferation of human gingival fibroblasts. Lasers Surg Med 2002; 30(5):365-9.

9- Loevschall H, Arenholt-bindslev D. Effect of low-level diode laser irradiation of human oral mucosa fibroblasts in vitro. Lasers Surg Med 1994;14(4):347-54. 
10- Mester E, Mester A, Mester A. The biomedical effects of laser application. Lasers Surg Med 1985; 5(1):31-9.

11- Neiburger EJ. Rapid healing of gingival incisions by the HeliumNeon diode laser. J Mass dent Soc 1999; 48(1):8-13.

12- Rydén H, Persson L, Prever H, Bergström J. Effect of low power level energy laser irradiation on gingival inflammation. Swed dent J 1994; 18(1-2):35-41.

13- Sakurai Y, Yamaguchi M, Abiko Y. Inhibitory effect of low level laser irradiation on LPS-stimulated prostaglandin E2 production and cyclooxygenase-2 in human gingival fibroblasts. Europ J Oral Sci 2000; 108(1):29-34.

14- Tunér J, Hode L. It's all in the parameters: A critical analysis of some well-known negative studies on low-level laser therapy. J clin Laser Med Surg 1998; 16(5):245-8.

15- Tunér J, Hode L. Laser therapy in dentistry and medicine. Edsbruk: Prima Books; 1996.

16- Yu W, Naim JO, Raymond J, Lanzame MD. The effects of photo-irradiation on the secretion of TGF-b \& PDGF from fibroblasts in vitro [abstract 34]. Lasers Surg Med 1994; suppl 6:8. 